\title{
QUALITY OF WORK LIFE IN COLOMBIA: A MULTIDIMENSIONAL FUZZY INDICATOR
}

\author{
Mónica Sofía Gómez-Salcedo \\ Luis Armando Galvis-Aponte \\ Vicente Royuela ${ }^{1}$
}

\begin{abstract}
Quality of Work encompasses multiple objective and subjective dimensions, which may include labor income, job stability, job satisfaction, and social security. This paper follows the method proposed by Gómez et al. (2013) that introduces a new way of measuring Quality of Work, which consists of i) the use of Sen's functioning and capabilities approach and ii) a fuzzy sets method to define membership to the sets of good job quality. Using the Gran Encuesta Integrada de Hogares, we obtain results at the national level about age, gender, educational level, firm size, and industry sector. The results are consistent with previous literature. One topic that is highlighted from our results is the existence of a "Quality of Work Life Cycle", with higher levels of the index up to age 30, that may have critical implications for the social security system; people with lower quality jobs may not be contributing to health and pension funds, leaving many people without access to a retirement fund and implying more demands on the subsidized system to cover health expenses.
\end{abstract}

\section{Key words: Quality of Work, Fuzzy Sets, labor market, Colombia.}

JEL classification: J81, J89, J46, C02.

\footnotetext{
1 In order authors are Researcher of the Observatorio del Caribe Colombiano (+573165122447, msgomezsa@gmail.com); Researcher of the Centro de Estudios Económicos Regionales-CEER of the Banco de la República-Cartagena (+5756600808, lgalviap@banrep.gov.co) and senior researcher of the AQR-IREA of the University of Barcelona (+34934035732, vroyuela@ub.edu). Acknowledgements: This research was funded in part by a grant to Mónica Sofía Gómez, with resources coming from the Administrative Department of Science, Technology and Innovation-COLCIENCIAS. Any errors are responsibility of the authors alone. Vicente Royuela acknowledges the support of ECO2013-41022-R.
} 


\section{QUALITY OF WORK LIFE IN COLOMBIA: A MULTIDIMENSIONAL FUZZY INDICATOR}

\section{Introduction}

The aim of this paper is to analyze the Quality of Work (QoW) in Colombia using a fuzzy sets method. The paper builds upon the work of Gómez et al. (2013), who worked in the Chilean case study and didn't include subjective dimensions to measure the quality of work. We also study a recent period of the labor market in Colombia (up to 2015). It is important to note that, despite the suitability of this method for the analysis of QoW, few experiences have been applied in the literature and up to now none of them has analyzed a non OECD country.

By not imposing subjective weights we are able to find which dimensions are the most important to determine the QoW. In this regard, we find that the main determinants of QoW of the Colombian labor market are labor stability, working conditions and social security, the latter associated with informality. A result that contrasts with other works using fuzzy sets methods, such that of Agovino and Parodi (2014) for the case of Italy, in which seniority and institutional factors are the variables contributing the most to the score of work quality. Job quality in OECD is characterized by age and skills type of work: youth, low skilled and non-standard work (temporary and part time) tend to be associated with weaker job quality outcomes (see chapter 3 of OECD, 2014a). Colombia is negotiating to be accepted in that "club" since 2013. Consequently, some improvements in the Colombian labor market conditions may be required in order for Colombiato be accepted in the OECD. In our research we also find a QoW life cycle, with a peak about age 30. Besides, the huge increase in QoW is stronger in younger ages, what can be a consequence that better jobs are occupied by younger, usually better educated, workers.

QoW is at the forefront of institutional concerns (ILO, OECD; European Union) in many spheres related to the labor market. Of course, the policy targets are beyond the definition of a good job or what can be called QoW, a concept that was previously analyzed in works such as Freeman (1978), Rosenthal (1989), and Gittleman and Howell (1995)².

A consensus in the literature is that QoW is multidimensional, and it is generally accepted that it is necessary to "deconstruct the concept" (Rogerson 1997) either into its measurable components or into the different processes involved. Next, the measurements need to be represented either jointly or separately as an index or a profile. Therefore, evaluative assumptions have to be used to establish relationships between the components to manage and give the final shape to the composite measurement. Another consensus in the literature is that QoW should be defined as the sum of two fundamental axes: those related to psychological mechanisms, producing a feeling of satisfaction with life, and external conditions that make the internal mechanism work.

\footnotetext{
${ }^{2}$ For a review of how the QoW concept has been dealt with in the academic literature, see Martel and Dupuis (2006) and Dahl et al. (2009).
} 
Dupuis et al. (2000) report a general definition of quality of life: "quality of life, at a given time, is a state that corresponds to the level attained by a person in the pursuit of her hierarchically organised goals"' (p. 107). Martel and Dupuis (2006) apply this definition to QoW life and propose 33 domains to give an overall definition of QoW, linked to the four major dimensions of Turcotte (1988) and the 14 domains of Kohl and Shooler (1982).

Some authors work with objective measurements that relate mostly to economic approaches and directly consider aspects related to work characteristics and its context, such as wages, workplace, work schedules, etc. (Dahl et al. 2009). Other sociological works (e.g., Jencks et al. 1988; Gruenberg 1980; Blank 1990) consider subjective perceptions of workers, mostly associated with certain conditions of their work but also with the generic concept of job satisfaction and overall job quality. The authors supporting the use of worker perceptions claim that this is the best way to know worker preferences and utility. Although there is a vast literature considering such an approach (see Freeman 1978; Clark 1996, 2005; Ritter 2005; Davoine 2006; Kalleberg and Marsden 2012) it is not absent of critique. Those who disagree with such a methodology argue that findings may lack objectivity, because study participants are influenced by emotional factors at the time of the survey or in the interpretation of problems (Spector 1997; Muñoz de Bustillo Llorente and Fernández Macías 2005). Embracing both approaches, it is possible to combine objective and subjective information in a joint measurement of QoW, combining worker characteristics and the subjective evaluation of these characteristics by the individual (see for instance Royuela et al. 2008; Royuela et al. 2009; Iglesias et al. 2011; Royuela and Suriñach 2012), as well as job conditions.

The multidimensionality of the concept, together with the need to summarize it in a composite measurement, drives us to consider which technique is more appropriate. The OECD (2008) recommends following a list of steps wherein weighting and aggregating the data on the dimensions arise as a key issue. In particular, compensability among indicators has been widely studied in fuzzy set theory (Zimmermann \& Zysno 1983). This technique is quite new and has been applied in the analysis of QoW in a few other studies. As recognized in Agovino and Parodi (2014), choices underlying both objective and subjective indicators are ambiguous. In such circumstances, fuzzy sets theory permits a meaningful representation of such outcomes. One of its main advantages is that it is a suitable mathematical tool to analyze concepts that are hard to place in a set. Thus, a classical set is just a container that wholly includes or wholly excludes any given element. On the contrary, in a fuzzy set an element is allowed to partially belong to a set, which represents its membership ranging from non-membership (0) to full membership (1).

In this work, we focus on Colombia, a Latin American developing country where the labor market is characterized by large but decreasing unemployment rates (10 percent on average in the last decade). As in many other developing countries, the Colombian labor market has a large proportion of informal jobs, with particular characteristics usually linked to low QoW. Informal jobs are themselves ambiguous, as the spectrum ranges from unpaid family workers, self-employment, street vendors, and even small-scale businesses. We consider new data (up to 2015) and expand the dimensions and the indicators explored in earlier literature by considering 17 variables. For the first time in Colombia we use the fuzzy sets technique to calculate our QoW Index (QoWI). This approach allows us to build an index associated to every individual, which in turn permits us to summarize the characteristics of the Colombian labor market in that respect. Our results point to low levels of QoW, with little 
differences by gender and with higher levels in highly educated workers and for those employed in bigger firms. As expected, formal jobs have disproportionally higher QoW levels, while we find a "Quality of Work Life Cycle", with higher levels of the index up to age 30.

The paper is structured as follows. The second section discusses the case study and reviews previous results. The third section presents the data used for the empirical exercise. The fourth reviews the fuzzy sets theory and explains its application to the analysis of QoW. The basic results are given in section five, and a conclusion of the main findings is provided in section six.

\section{Quality of Work life in Colombia}

\subsection{Overview of the labor market}

Colombia is a South American middle-income country, with coasts on the Atlantic and Pacific oceans and sharing borders with Venezuela, Brazil, Ecuador and Peru. According to the OECD (2013a) in 2011 Colombia ranked third among the countries of Latin America and the Caribbean in size of population (46.9 million people) and labor (22.1 million people); fourth in GDP (474 billion dollars in Purchasing Power Parity-PPP); and fifth in area $\left(1,142,000 \mathrm{~km}^{2}\right)$. As a matter of fact, since 2000 Colombia has shown a growth rate of GDP above the average of the Latin American \& Caribbean countries (excluding 2004 and 2010) and OECD members (see Figure 1a).

In spite of those favorable statistics, inequalities and income concentration are also high: between 2000 and 2012 the average annual Gini coefficient was 56\%, exceeding both South American and OECD countries. On the other hand, poverty rate in Colombia has declined as well as unemployment, largely due to economic growth in recent decades (fueled by the production of raw-hydrocarbon materials), integration of the country into the world economy, better governance and the reduction of armed conflict (OECD 2014b). In terms of labor market indicators, although the employment rate shows a rising trend since 2000 and is higher than the average of OECD members, it remains below the average for Latin America and the Caribbean (see Figure 1b). According to the OECD (2014a) the unemployment rate "remains high among OECD and Latin American countries and most people who work do so in the informal economy, often in low-productivity" (see Figure 1c and Appendix 1).

Employment figures are not entirely satisfactory noting the high rates of self-employed ${ }^{3}$ persons and informality ${ }^{4}$.

\footnotetext{
${ }^{3}$ The self-employed will be any person resident in the country whose revenues come in at or above eighty percent $(80 \%)$ of the making and service delivery at their own risk, of economic activities identified according to Law 1607/2012 and Decree 3032/2013.

${ }^{4}$ According to the National Administrative Department of Statistics-(DANE informal workers are persons who during the reference period were in one of the following situations: 1. Individual employees and workers who work in establishments, businesses or enterprises employing up to five persons in all its branches and agencies including the employer and / or members; 2 . family workers not compensated in companies with five employees or less; 3. workers not compensated in companies or businesses from other households; 4 . Domestic workers in firms with five or fewer workers; 5. Laborers in companies of five employees or less; 6. Self-employed persons working in establishments up to five people, excluding independent professionals; 7. Employers in companies with five employees or less; 8 . Workers or government employees are excluded.
} 
Figure 2 shows the downward trend in the unemployment rate between 2007 and 2013, accompanied by slight decreases in rates of informality and self-employment, however observed rates remain high: about 36\% of Colombian workers report being self-employed and about $50 \%$ are informal. This situation becomes even more critical when the differences within the country are examined as the more impoverished areas may reach informality rates up to $80 \%$ (Galvis, 2012).

Figure 1. Growth rate of GDP, Employment and Unemployment: Colombia-COL, Latin America \& Caribbean-LCN and OECD members-OED. 2000-2013.

a) Annual GDP growth rate

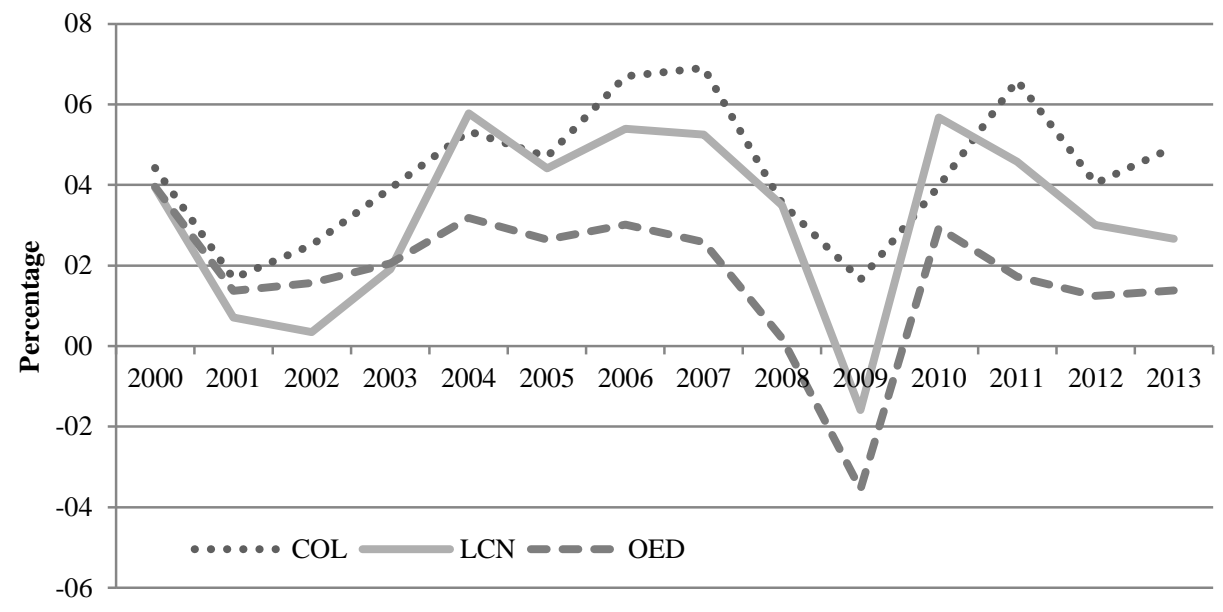

b) Employment to population ratio

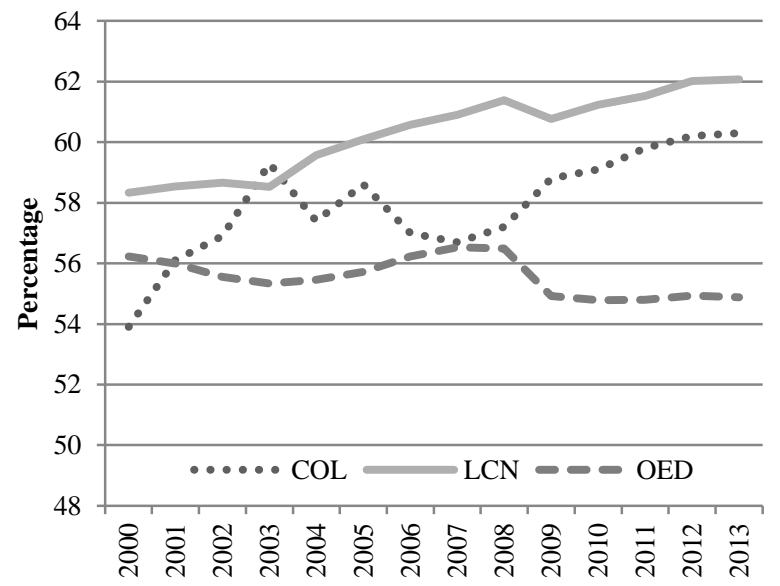

c) Unemployment

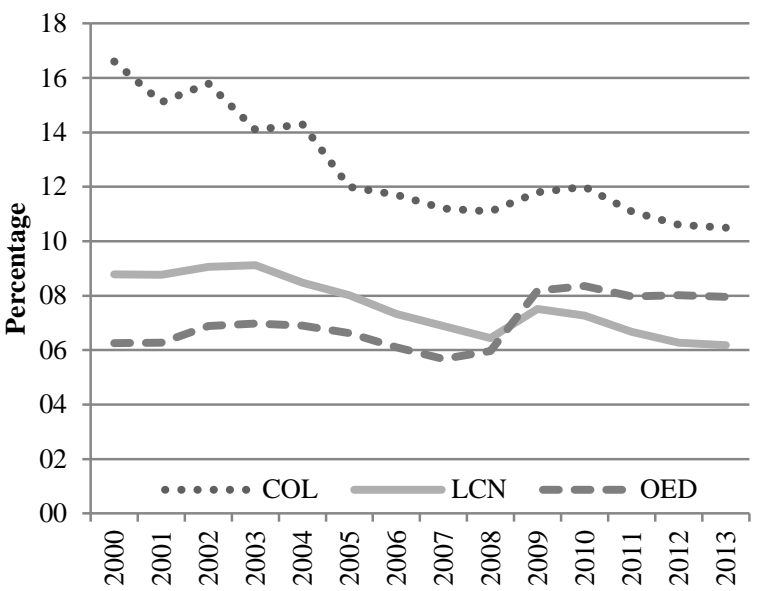

Source: Authors' elaboration based on data from the World Development Indicators, http://data.worldbank.org/. 
Figure 2. Labor Market Indicators: Overall Participation Rate-OPR, Employment Rate-ER, Unemployment Rate-UR, Self-employment and Informality. Colombia, 2007-2015.

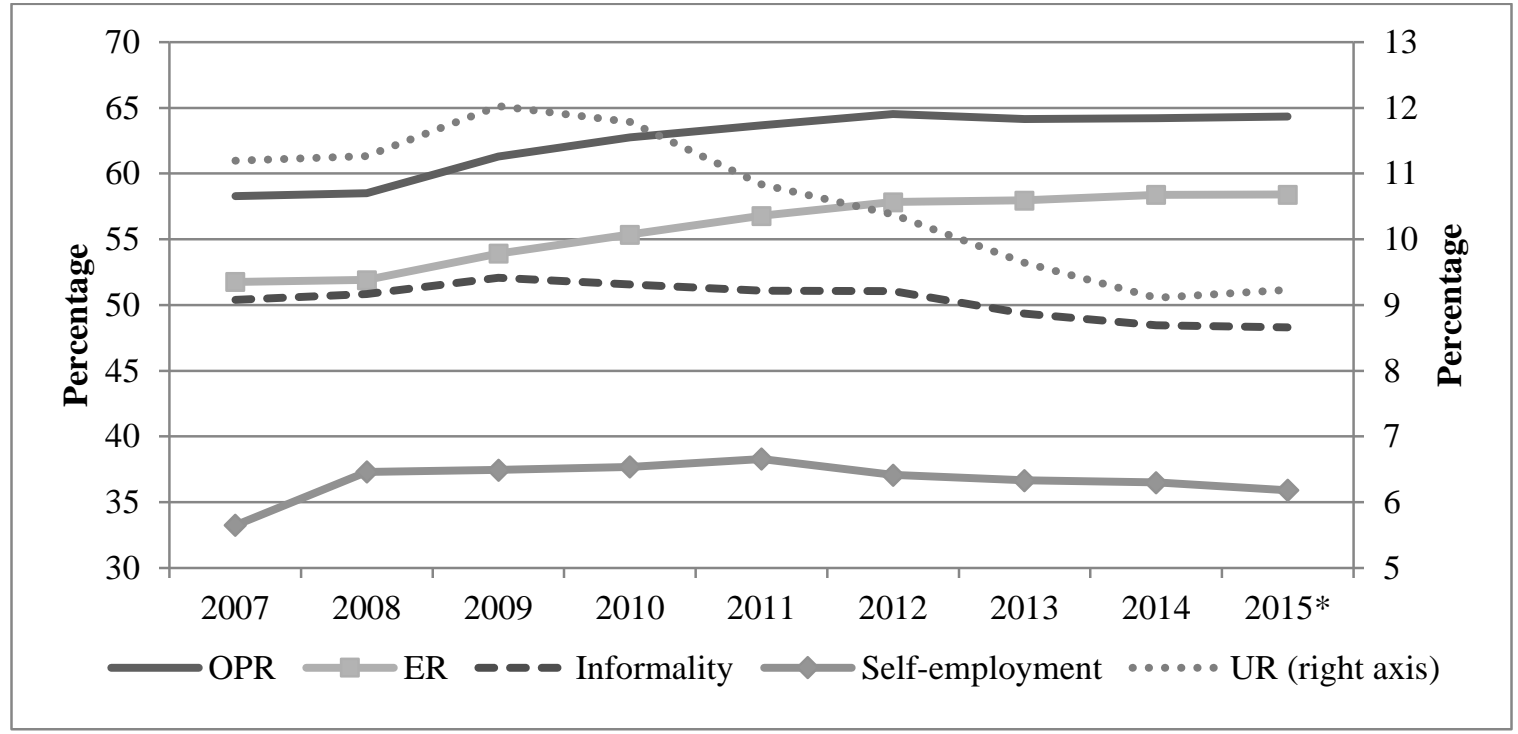

* Data obtained by averaging the first three quarters.

Source: Authors' elaboration based on data from the National Accounts at constant 2005 prices and GEIH

(Gran Encuesta Integrada de Hogares - Integrated Large Household Survey), DANE (Departamento Administrativo Nacional de Estadística - National Administrative Department of Statistics).

As Arango \& Hamann (2012) highlight, some of the Colombian labor market indicators suggest an outstanding dynamism; however, others point underperforming:

"Among the indicators that suggest a high market dynamism are: the major incursion of women in the labor market in the last quarter; large flows of people coming in and out of their conditions of employed, unemployed and inactive; the change in the relative composition of the workforce by educational level, showing a fall in the proportion of people who have, at most, primary education and an increase in the proportion of people with more years of formal education; mobility of labor to other countries; and the behavior of real wages in both the long term and the natural frequency of economic cycles.

On the other hand, among the indicators that suggest a market low performance we have: the excessive growth of the sector of outlaws (in other words, informal or irregular sector) which highlights the low level of productivity of labor; the existence of a structural unemployment rate has fluctuated between $9 \%$ and $12 \%$ in the last twenty years despite labor reforms; important levels reached by the indicators of underemployment; the increase in the unemployment rate in late 1994 and early 2001 at an average rate of $0.18 \%$ per month until reaching levels close to $20 \%$, and its slow decline, at an average rate of $0.11 \%$ per month, between June 2001 and December 2007; low internal mobility of labor; and persistent differences between the performance indicators of cities." (Arango \& Hamann 2012, p. XIII-XIV, authors' translation).

Regarding quality of work, the high degree of informality in the Colombian labor market is a matter of concern. Although we cannot generalize that being informal is synonymous of having a poor quality job, it is known that those workers usually do not have the same benefits of the formal ones 
affiliated to the public or the private sector. Thus, we expect to find that most of the workers in the country do not have a job of good quality.

\subsection{Previous results}

Quality of work can be measured using different aspects of a job, considering what each researcher judges relevant to investigate, as well as the particular characteristics of the country, city or region under study, and the statistical information available. Other aspects taken into account when measuring QoW are listed on Sen's capability and functioning approach in the sense that, as mentioned by Pineda \& Acosta (2011), "each dimension of the quality of work contributes to performances that allow or not to expand specific capabilities of performance, relationships, assessments and fields of choices and freedoms" ( $\mathrm{p} 78$, authors' translation). However, it is possible to find some common variables such as income, job satisfaction, social security, job security, working hours and shifts and ways of recruitment.

In the Colombian literature, since the beginning of 2000, we can observe an increasing interest of several authors in measuring the quality of work in the country, using different methods and variables (see Appendix 2). For the previous works, in general, the data correspond to the period 1997 - 2012 coming from the Gran Encuesta Integrada de Hogares -GEIH-, a household survey conducted in Colombia. When analyzing the dimensions that make up the QoWI we can observe that there is coherence with the international literature, even regarding the ongoing debate on the use of objective and subjective variables. Specifically, the most recent documents incorporate variables related to job satisfaction, which pertains to the realms of subjective indicators (e.g. Pineda and Acosta 2011; Farné et al. 2011; Quiñones 2011; Observatorio del Mercado Laboral de Cartagena y Bolivar 2013).

To calculate the QoWI, several authors follow a methodology that defines ad hoc weights for the dimensions that the index includes (Farné 2003; Ortiz et al. 2007; Bustamante and Arroyo 2008; Posso 2010; Mora and Ulloa 2011; Quiñones 2011). Other authors follow a different approach by calculating the weights using methodologies such as Principal Components- PC (Pineda and Acosta 2011; Farné et al. 2011; Quiñones 2011; Observatorio del Mercado Laboral de Cartagena y Bolívar 2013); and Multiple Correspondence Analysis (Jiménez and Páez 2014).

The overall results indicate that, on average, workers located in the thirteen main cities and metropolitan areas in Colombia have low QoW. There are large differences between the selfemployed workers (informal jobs) and the paid workers (formal jobs), with advantages for the latter. This is due to the intrinsic characteristics of each group; paid workers have labor contracts that guarantee them access to the benefits that are granted by law. By gender, in the Colombian literature about quality of work, a few authors have found no significant differences between men and women; but most of the works on this respect find differences in favor of men.

On the other hand, jobs associated to government and services activities display on average higher quality levels. This is mainly due to the regulations governing the Colombian public sector, and the good working conditions in the services sector (such as contracts, higher wages and access to social security benefits). Within the territory, there are differences between the thirteen main metropolitan areas, being Medellin and Bogota the cities with the highest average rates of job quality, as opposed 
to Monteria and Cucuta that remain lagging behind. The first two cities mentioned are the most important urban areas in the country in terms of population and economic characteristics.

Looking the variables studied, authors suggest that in addition to an increase in underemployment, part-time work, long-term unemployment and informality, they observed little progress in affiliation to social security (health and pension). In the last seven years (2007-2014) it seems that the situation with social security has improved: the percentage of workers affiliated to the health system increased 7.8 percentage points (p.p), while the corresponding figure affiliated to pension increased 4.3 p.p. However, the increase in health coverage is because of an increase in the quantity of workers affiliated to the subsidized regime (the public system) as opposed to the contributing one. The data also revealed that outsourcing has increased and the salaries of many workers have grown too slowly, causing a significant increase in income underemployment. Finally, the percentage of workers who benefit from family subsidies has declined over time.

\section{Data}

The data we use to carry out the empirical analyses come from the GEIH for the years 2009-2015. This survey, conducted by the National Administrative Department of Statistics-DANE. It is conducted as a probabilistic, multistage, stratified sampling with unequal and self-weighted clusters (for twenty-four capital cities with their metropolitan areas). The target population corresponds to the non-institutional civilian population living in the country. The monthly sample size corresponds to 20.669 households. It has national coverage that provides results for total urban and rural areas, major regions and by department, according to the political division studied ${ }^{5}$.

To compare results we focus on two years 2009 and 2015, because usually no dramatic changes are observed every year. The publicly available data includes up to the third quarter of the year 2015 , whereas the year 2009 have complete information. However, we did not include annual data for the year previous to 2015 in order not to have inconsistencies with the comparison with the last available data, which solely comprises three quarters. Then, for each of the years under study, the sample consists of data from the second and third quarters. The objective of this choice is twofold: first, to cover a larger population; and second, to prevent the effects of the seasonality of the series.

Therefore, taking into account the level of representativeness of the publicly available data, this study will be focused on the thirteen main cities and metropolitan areas. Namely: Barranquilla, Bogota, Bucaramanga, Cali, Cartagena, Cucuta, Ibague, Manizales, Medellin, Monteria, Pasto, Pereira and Villavicencio. According to the population projections, in 2015 these cities and metropolitan areas accounted for $46.1 \%$ of the national total and $58.2 \%$ of the total urban population.

In addition, the sample taken solely considers the employed population ranging between ages of 12 to 62 years. This range pertains to the definition of the labor force. Beyond 62 the retirement age is reached. For 2009 we have a sample of 63,870 observations which correspond to an expanded

\footnotetext{
${ }^{5}$ Political divisions of Colombia correspond to municipalities, departments and regions.
} 
database of $6,771,513$; for 2015 the sample size is 72,682 , which is equivalent to an expanded database of $8,930,820$ individuals.

As for the dimensions and variables that will be used to calculate the QoWI, we have followed Turcotte (1988) and we have searched for indicators describing the nature of the job itself and also for capturing the psychosocial context or subjective perception of QoW. As it happens in works, such as ours, that deal with data coming from administrative surveys, the objective measurements are over represented, while the main focus of the academic definitions of QoW is individuals' perceptions of their feelings and environment (see Royuela et al. 2008 for a comparison between the academic definition of QoW and the one resulting from the European Commission). Here we follow a strategy that is close to the one developed by previous research in Colombia (see Appendix 2). The selection has been based on data availability, which is strongly associated to material conditions of jobs. We find dimensions that are common in the literature for Colombia. Namely: labor intensity, workplace, labor income, social security and labor stability, regarding the objective indicators; while the underemployment and job satisfaction, are in the group of subjective indicators. Our QoWI includes six dimensions, namely: working conditions, labor income, social security, labor stability, employment satisfaction and underemployment. These dimensions comprise a total of 17 variables (Table 1). Those variables were categorized so that a higher value implies a better job quality.

In general, if we compare the summary statistics between 2009 and 2015 we can observe an increase in the mean of 10 variables: Hours worked, Workplace, Overtime paid, Affiliation to pension, Affiliation to health services, Professional Risk Coverage (ARL), Severance payments, Union membership, Job stability and Underemployment. This means that, the data exhibit a decrease in the percentage of workers with the worst labor conditions (under category number 1), improving the percentage of employees with better labor conditions. However, other variables show a worse situation for the working conditions. Namely, Income (in relation to the minimum wage), Subsidies, Tenure, Term and type of contract, Job satisfaction and Work-family compatibility. The statistics for Second job show that the there is no changes in this variable (summary statistics are displayed in Appendix 3).

Table 1. Dimensions and variables to the quality of work index.

\begin{tabular}{lll}
\hline \multicolumn{1}{c}{ Dimension } & \multicolumn{1}{c}{ Variable } \\
\hline \multirow{2}{*}{ Working Conditions } & - Hours worked \\
& - & Workplace \\
Income & - & Overtime paid \\
& - & Income (in relation to the minimum wage) \\
& - & Subsidies \\
Social Security & - & Affiliation to pension \\
& - & Affiliation to health services \\
& - & Professional Risk Coverage (ARL) \\
Labor Stability & - & Severance payments \\
& - & Union membership \\
& - & Tenure \\
Employment Perception & - & Term and type of contract \\
& - & Job satisfaction \\
\end{tabular}




\section{Fuzzy sets applied to quality of work}

Following Sen's approach (1999), we propose to use Fuzzy sets method to build the QoWI. In contrast to the use of binary measurements, the method of fuzzy sets has some advantages. For example, it is an appropriate mathematical tool for analyzing the concepts that are difficult to place in a set of wholly membership. In this method the result of the index allows to infer the partial membership, which is represented by a function that maps into the interval $[0,1]$. If we are dealing with the characteristics of the job, having a job of good quality is represented as having a full membership, with a value of 1 for the membership function. Likewise, a value of zero for the function represents a job of poor quality.

This method has been applied in researches focused on the analysis of Quality of Life or poverty (for example Lelli 2001; Lemmi \& Betti 2006; Bérenger \& Verdier-Chouchane 2007). Huneeus et al. (2012), state that "the poverty phenomenon is similar to the employment phenomenon and they are in fact economically connected, although they use different dimensions" (p.8). Hence, the analysis of one of them can be applied to some extent to the study of the other. Cheli and Lemmi (1995) argue that when there are economic, non-economic, and subjective observations we face a version of Fuzzy Sets, the Totally Fuzzy and Relative-TFR because: i) for any individual the degree of deprivation relative to each item depends on his position in the distribution of that item in the society; (ii) the relative importance of every poverty indicator in the whole poverty analysis is determined by the frequency of the poverty symptoms directly observed" (p. 124). Despite the suitability of the method for the analysis of QoW, it has only recently been applied. Previous experiences can be found in Gómez et al. (2013) for the Chilean case and Agovino \& Parodi (2014) for the Italian one.

The mathematical formulation of the index follows the proposal by Lelli (2001). Let $X$ be the universe composed by individuals denoted by $x_{i}$ such that $i=1, \ldots, n$. Individuals have a vector of attributes or characteristics $j=1, \ldots, J$. Let $A$ be a fuzzy subset of $X$. If $x_{i} \in A$ individual $i$ does not suffer from deprivation of any attribute.

If the degree of membership of $x_{i}$ to $A$ can be expressed as a function $\mu_{A}$, which takes values in the interval [0,1], then $A$ is a fuzzy set. This way $A$ can be seen as $A=\left\{\left(x_{i}, \mu_{A}\left(x_{i}\right)\right), x_{i} \in X\right\}$. Function $\mu_{A}$ is defined as:

$$
\begin{aligned}
& \mu_{A}\left(x_{i j}\right)=0 \text { in case } x_{i} \text { does not belong to } A . \\
& \mu_{A}\left(x_{i j}\right) \in(0,1) \quad \begin{array}{l}
\text { in case of partial membership to subset } A . \text { This implies the total or partial } \\
\text { deprivation of several attributes, but not all of them. }
\end{array} \\
& \mu_{A}\left(x_{i j}\right)=1 \text { in case } x_{i} \text { has total membership to } A .
\end{aligned}
$$


$\mu_{A}\left(x_{i j}\right)$ is defined as an individual measurement of specific deprivation for indicator $j$. The only condition a membership function must satisfy is that it has to range in between 0 and 1 . Among the alternative definitions for evaluating the degree of membership, distance and frequency have proved to be helpful. Lelli (2001) recommends using the cumulated distribution, as it allows avoiding arbitrary threshold definitions. In addition it allows to obtain evaluations for every considered dimension. Cheli and Lemmi (1995) propose the following function:

$$
\mu_{A}\left(x_{i j}\right)=\mu_{A}\left(x_{j}^{(k)}\right)= \begin{cases}0 & \text { if } x_{i j}=x_{j}^{k} ; k=1 \\ \mu_{A}\left(x_{j}^{k-1}\right)+\frac{F\left(x_{j}^{k}\right)-F\left(x_{j}^{k-1}\right)}{1-F\left(x_{j}^{1}\right)} & \text { if } x_{i j}=x_{j}^{k} ; k>1 \\ 1 & \text { if } x_{i j}=x_{j}^{k} ; k=K\end{cases}
$$

Where $k=1, \ldots, K$ is the risk of deprivation, such that the higher $k$ the lower deprivation, being then $K$ the lower deprivation level and $F\left(x_{j}\right)$ the cumulated distribution of variable $j$, classified according to $k$. The QoWI for every individual is computed as the weighted average of all membership functions:

$$
Q o W I_{i}=\frac{\sum_{j=1}^{J} \mu_{A}\left(x_{i j}\right) W_{j}}{\sum_{j=1}^{J} W_{j}}
$$

Where $J$ represents the total number of dimensions and $W_{j}$ refers to the corresponding weight, which is computed as:

$$
W_{j}=\ln \left[\frac{1}{\frac{1}{n} \sum_{i=1}^{n} \mu_{A}\left(x_{i j}\right)}\right]
$$

Where $\frac{1}{n} \sum_{i=1}^{n} \mu_{A}\left(x_{i j}\right)$ represents the fuzzy proportion of individuals with some degree of QoW in attribute $j$. The final outcome of this method is an index measuring QoW at the individual level. The aggregation for different dimensions (such as age, gender or economic sector) allows us to characterize the Colombian labor market.

It is important to note that this approach overcomes certain limitations that are inherent to other methods used previously to calculate QoWI. First, it does not require us to come up with subjective weights for the dimensions. Second, the weighting scheme employed by the fuzzy indicator is sensible to the frequency of every attribute, giving fewer loads to less frequent or unusual employment characteristics. Third, it does not rely solely on the loads of the dimensions as Factor Analysis or Principal Components do, ignoring the social environment in which individuals develop their work life. When employing Fuzzy sets we pay attention to the characteristics of the social environment of the jobs, in the sense that the degree of membership takes into account the cumulated distribution of all dimensions and weights them by the frequency of the higher level of deprivation [i.e.: $1-$ $\left.F\left(x_{j}^{1}\right)\right]$. This approach follows the intuition by Desai and Shah (1988), who propose that the social environment is an important factor when measuring deprivation. In our case the social environment, where the individuals work, is important to determine deprivation from jobs of good quality. 


\section{Results}

Before getting into the analysis of the results of the QoWI, we will analyze the results in terms of the weights that the method yields for each dimension. In all the period, 2009 to 2015, in order of importance we find labor stability, working conditions and social security as the most salient ones for the calculation of the index. It is important to note that, labor stability and social security have been found to be significant determinants of the quality of work in the Colombian literature. Analyzing single variables, union membership and payments for overtime are the ones with higher weights. This is due to the fact that regarding those variables most of the workers are in the less desirable situation, that is: most of the workers do not have union affiliation nor overtime paid.

Given the relevance of labor stability, working conditions and social security dimensions in the calculation of the index, we may highlight that for the labor force to improve its QoWI it would be necessary to propose policies to improve such variables. For instance, in the dimension labor stability 96.4\% of the workers in 2015 reported not to be affiliated to a union, $41 \%$ are in a job with tenure of one year or less, and $31.5 \%$ said not to have any type of contract. Those workers under such conditions have the worst situation in terms of the variables union membership, tenure and term and type of contract. Currently, firms and government have no policies to tackle such problems. About social security, the government designed a unified format to make workers contribute to health and pension funds, named the Integrated Contribution Liquidation Form (Planilla Integrada de Liquidación de Aportes, PILA), which was mandatory from July 2013. There was, however, a negative implication of this policy: self-employees with lower wages (lower than the minimum) chose not to contribute to social security due to the highly expensive burden that it represented for them (approximately $28.5 \%$ of the wage). As a result, in 2015 the data show that $47 \%$ of workers are not contributing to the pension funds, $42.4 \%$ are not affiliated to health services and $47.7 \%$ do not have coverage for professional risks.

Figure 3. Quality of Work Life Index, 2009-2015. 


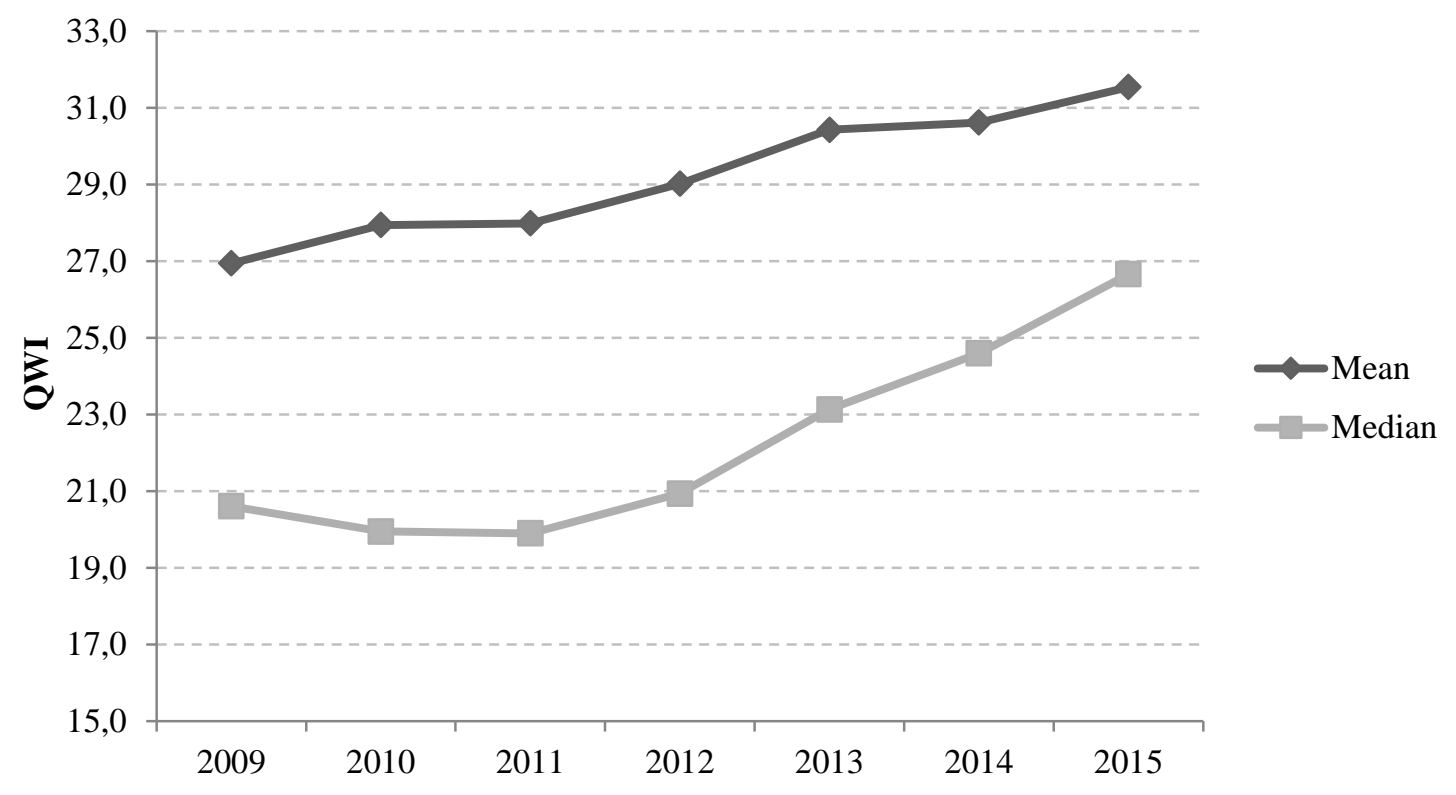

Source: Authors' calculations based on data from the GEIH-DANE.

In 2009 Colombian workers had on average low levels on the QoWI, being the average 26.9 out of a total of 100 possible points. In 2015 the average index improves, reaching a value of 31.5, but still remains low. If we observe the behavior of the index throughout 2009-2015, it is interesting to note that there is a sustained growth trend in the mean of the index. The median exhibits a slight decrease but overall it also shows improvements throughout the period (Figure 3). The strong difference between the mean and the median is an indicator of strong skewness in the data, with large amount of workers with low levels on the QoWI and few workers with good standards. These large differences arise when we analyze types of work: formal workers have on average better quality than the informal ones. In this case, the difference is about 25 points in the QoWI. Although we observe a slight improvement in the index in 2015 for both groups, the relative difference between them remains (see Figure 4).

In contrast with the type of job, the index shows just a slight difference between genders, what can be interpreted as a lack of gender discrimination in the labor market. The Colombian literature about quality of work shows differences in favor of men at the national level (see Ortiz et al. 2007; Mora \& Ulloa 2011; Pineda \& Acosta 2011; and Farné et al. 2011); only one document, at local level, finds that women have better quality of work than men (see Observatorio del Mercado Laboral de Cartagena y Bolivar 2013). In our results we find both outcomes: in 2009 women had higher levels of the QoWI than men, while in 2015 men have increased more the index, and enjoy higher levels than women (see Figure 5).

Figure 4. Quality of Work Life Index by Informality, 2009 and 2015. 


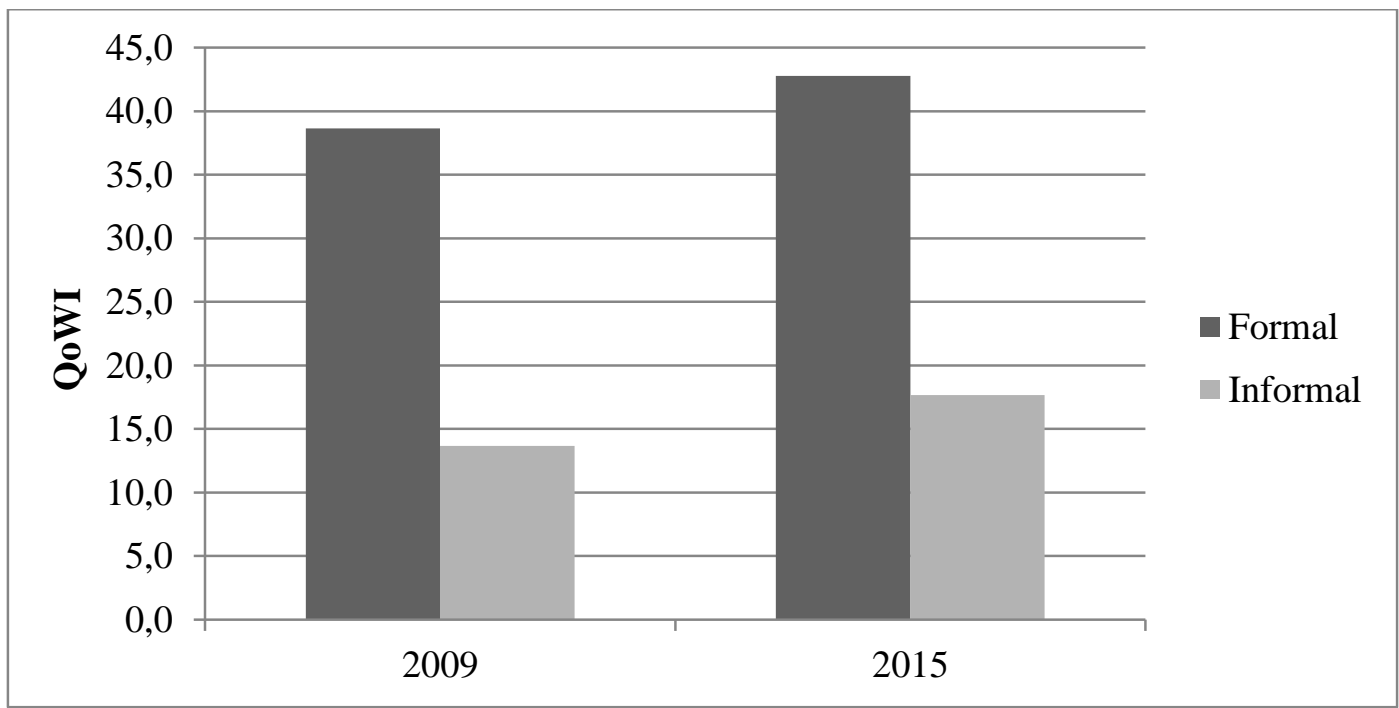

Source: Authors' calculations based on data from the GEIH-DANE.

Figure 5. Quality of Work Life Index by Gender, 2009 and 2015.

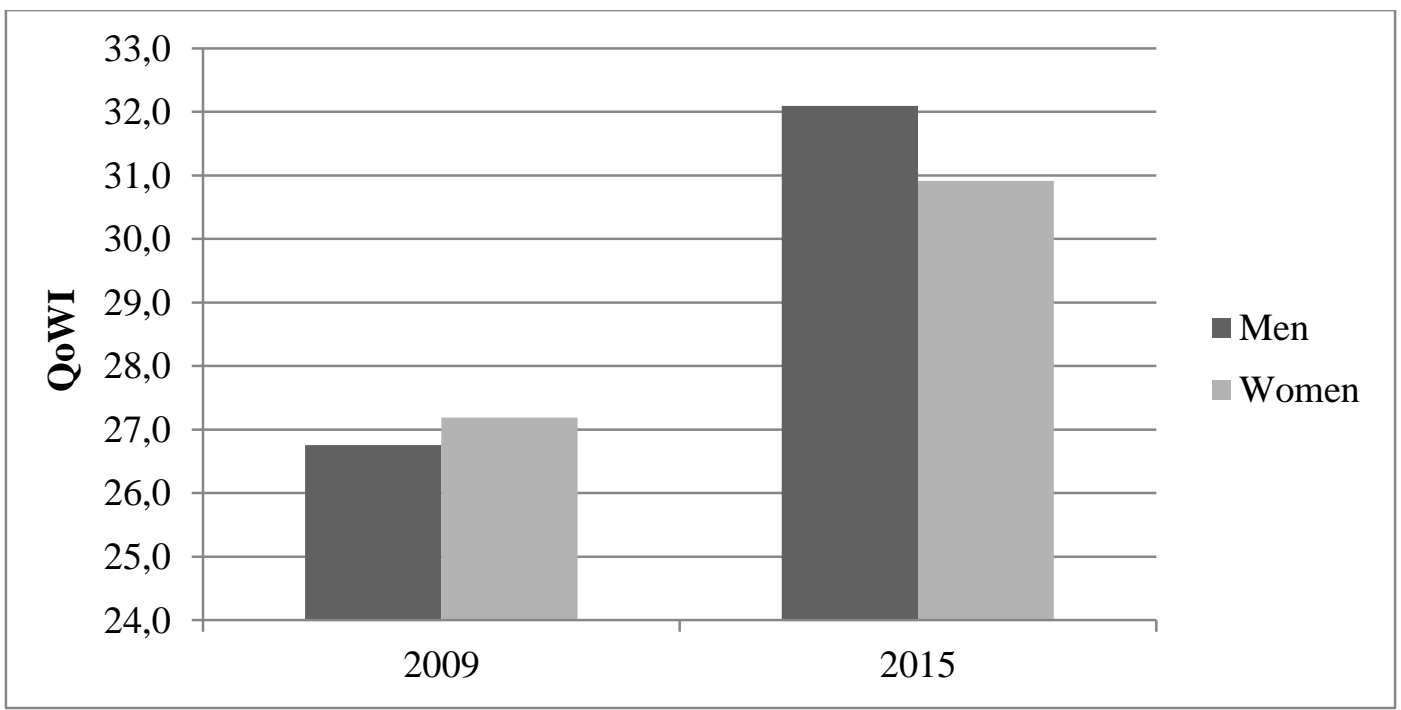

Source: Authors' calculations based on data from the GEIH-DANE.

According to the age of the workers, we observe that in 2009 the average index shows an upward trend until about age 27, therein the average QoWI falls. In 2015, all cohorts benefit from higher levels of the QoWI, what implies that no age group is out of the improvement of the labor market conditions. The maximum of the index in 2015 is reached at the age of 30 and in general, index 
improvements are stronger in younger ages, what can be a consequence that better jobs are occupied by younger, usually better educated, workers (see Figure 6).

Figure 6. Quality of Work Life Index by Age, 2009 and 2015.

a) 2009

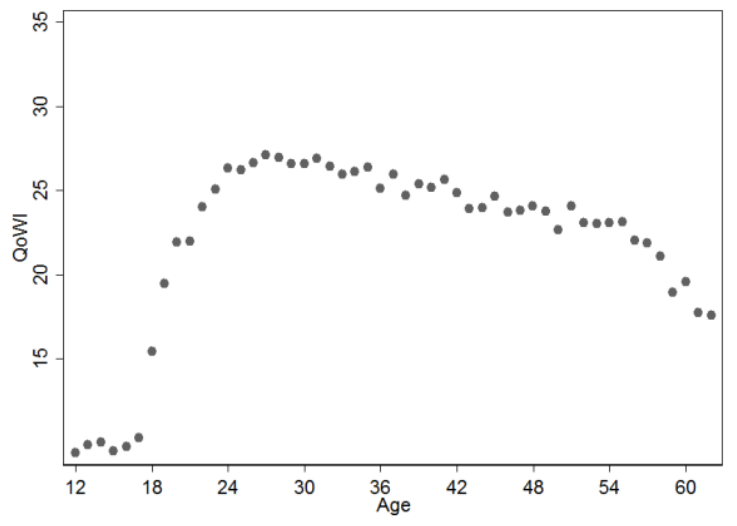

b) 2015

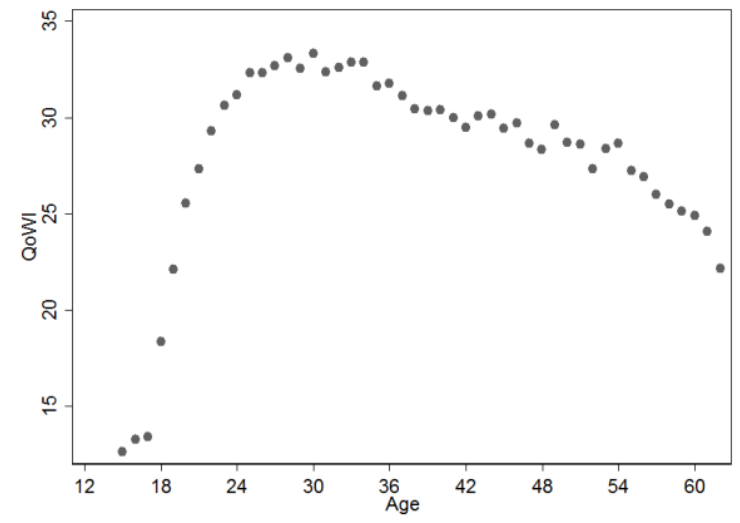

Source: Authors' calculations based on data from the GEIH-DANE.

If we separate the sample for each year of age, according to whether the workers are formal or informal, we find that most of the workers are classified as informal for two groups of them: those below 19 years old ${ }^{6}$ and the ones above 43 years old. Something similar related to this behavior has been documented by previous works on labor informality which refer to this fact as the "hypothesis of the work life cycle" (Ortiz and Uribe 2006; Galvis 2012). In this case, there seems to be a "cycle of quality of work" which appears to emerge from the results shown in Figure 6. At the beginning of the work life, people with lower skills are more prone to take on jobs with lower quality, as well as at the end of the work life cycle.

Linked with the previous analysis is the study of the QoWI by education attainment levels. Figure 7 displays a growing trend of the index with the years of schooling. In 2009, graduate workers had jobs with better QoWI (average of 39.1 points) than those with undergraduate degrees. Those with no degree completed have the worst index, reaching 19.7. By 2015, the situation is similar, but the average index is higher in all categories, with higher increases in the higher the education attainment: Graduates, 44.4 points; Bachelor, 39.2; Short-cycle tertiary education, 39.1; Secondary, 32.7; and None, 23.3. This means that the Colombian labor market rewards the efforts and investments of workers with high education levels.

Regarding the size of the company where individuals work, we observe similar results to those obtained in different works in the national and international context literature. Specifically, larger companies offer better quality jobs. In both 2009 and 2015 this result is confirmed (see Figure 8). Furthermore, the QoWI displays lower levels (below the average) for establishments up to 5 workers.

${ }^{6}$ This group represents minors under the Colombian regulations. 
The index grows at a decreasing rate with firm size until a threshold at 51-100 workers. Notwithstanding, the biggest firms (above 100 workers) are the ones with the highest QoWI.

Figure 7. Quality of Work Life Index by Educational Level, 2009 and 2015.

a) 2009

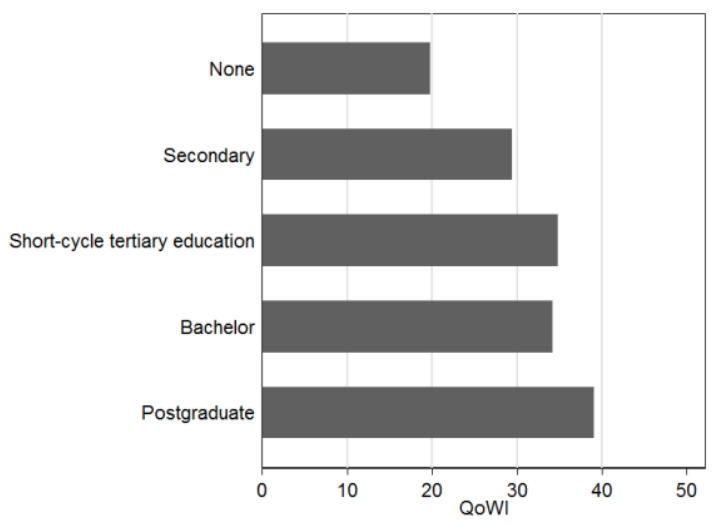

b) 2015

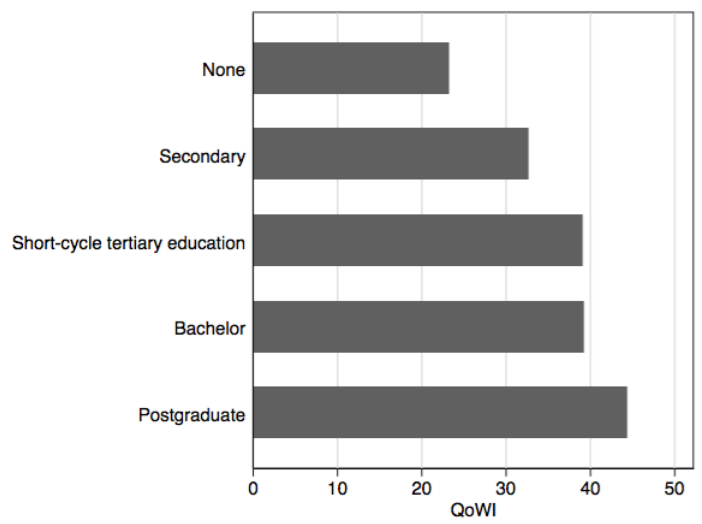

Source: Authors' calculations based on data from the GEIH-DANE.

Figure 8. Quality of Work Life Index by Company Size, 2009 and 2014.

a) 2009

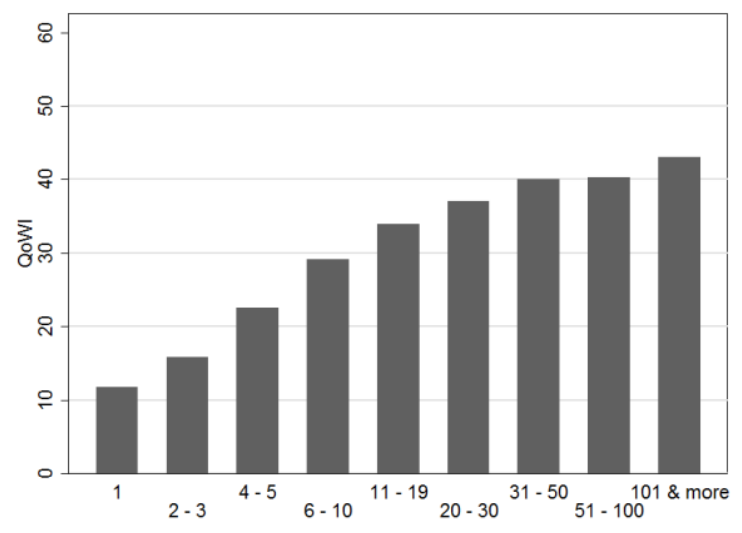

b) 2015

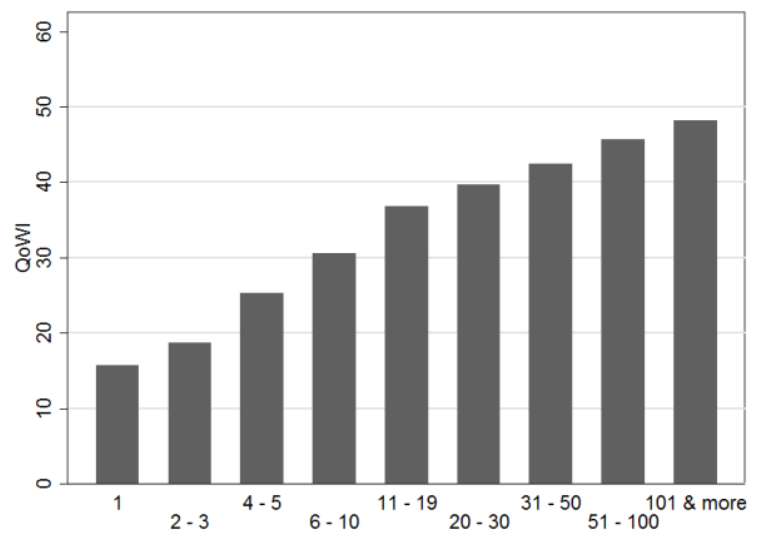

Source: Authors' calculations based on data from the GEIH-DANE.

By economic sector, the Electricity, Gas and Water (E.G.W.) and the Financial Intermediation ranked first and second respectively in the two years of study. Construction and Private Households are in the lowest positions of quality of job in 2009; but in 2015 ones ranking worst are Private Households and Hotels \& restaurants (see Figure 9). Analyzing the sample we observe that in 2009, as well as in 2015 , less than $3 \%$ of workers are involved in the first group of sectors. But the percentage of workers hired in the second group -with lower QoWI- increased: Construction 1.2 percentage points (p.p); Private Households 1.8 p.p and Hotels \& restaurants 2,2 p.p. Construction and Private Households 
are characterized to hire unskilled workers, which may not have bargaining power to access to good labor conditions. In addition, we can see that E.G.W, Mining, Real Estate Activities, Agriculture and Construction have been the fastest growing in the study period.

\section{Figure 9. Quality of Work Life Index by Economic Sector, 2009 and 2015.}
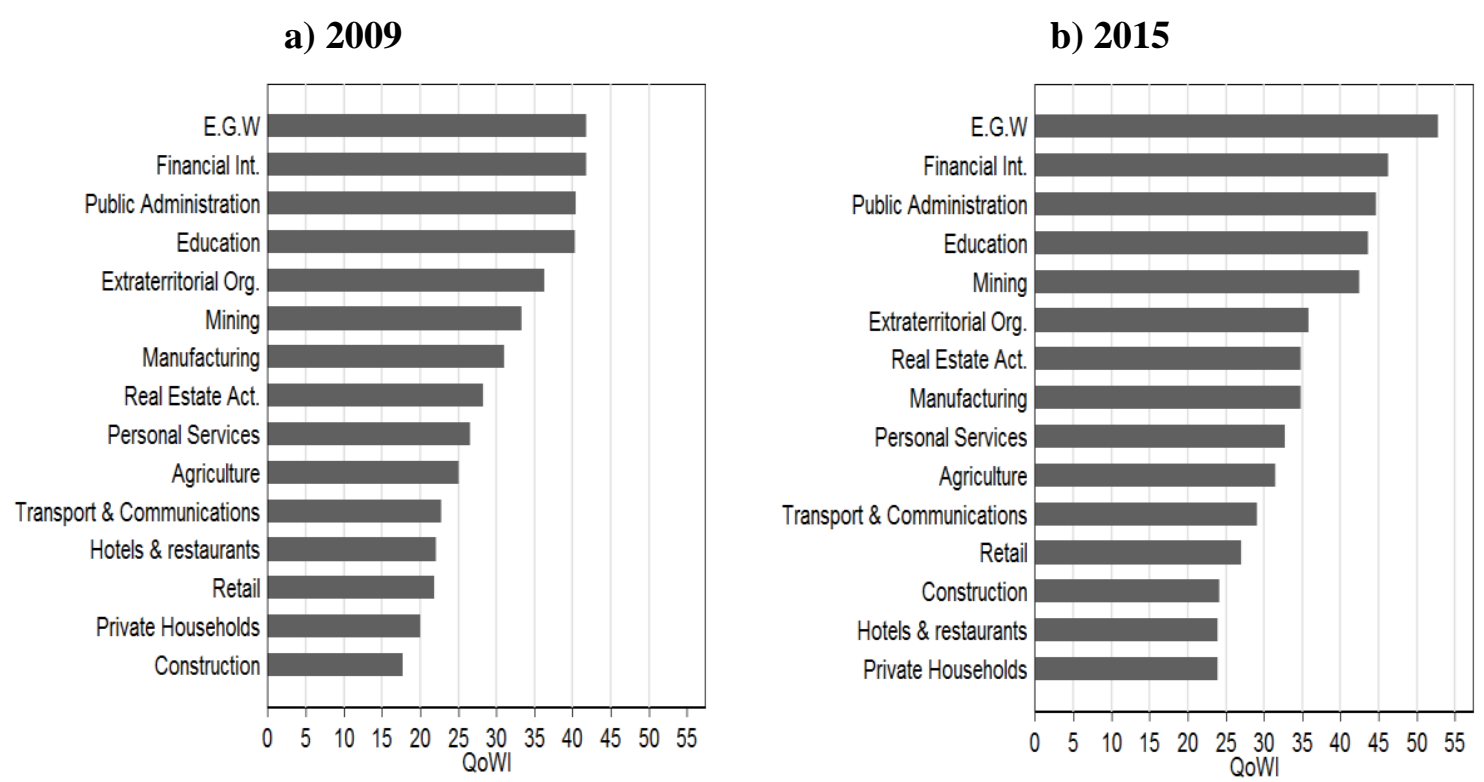

Source: Authors' calculations based on data from the GEIH-DANE.

\section{Concluding remarks}

In this paper we have analyzed QoW by means of a multidimensional fuzzy indicator applied to the Colombian labor market, comparing results for 2009 and 2015. As opposed to the works that yield an aggregated index, the results of this exercise yield an individual score for all workers, which is very important for policy makers, because it is possible to identify the most relevant dimensions or variables to categorize a job of high quality. Furthermore, it also allows us to set out the differences by worker characteristics, company, and industry sector.

The analysis of QoW in Colombia in recent years allows us to conclude that the labor market, on average, is of poor quality. We did not find great differences by gender. The QoW is much better for workers with high educational levels and who are employed at bigger firms, which matches the expectation regarding those variables.

The results point to the existence of a "Quality of Work Life Cycle", in which younger workers experience lower QoW. Quality increases with the age of the workers up to age 30 and then decreases. This implies that older people, on average, have fewer chances of getting a job of high quality. The explanation for such findings seems to originate from the fact that workers entering the labor market at young ages are endowed with lower education attainment, skills, and credentials to support their expertise. This drives most of the labor force to take on jobs with no benefits or to start their labor 
market experience as self-employed. As people start accumulating expertise in the job market, they become more qualified for jobs with more responsibilities and benefits, which very likely places them in the formal job sector and in jobs of higher quality. At the end of the life cycle, if people fall into unemployment they are again more prone to take on jobs that are informal or to work as selfemployed. The latter, as we have discussed, are situations in which the QoW is lower compared to the situation of formal sector workers.

The implications of the work life cycle point to two themes in the policy arena. First, for younger workers it would seem reasonable that the school system should retain them until they finish high school. This way, they will be more likely to be able to take on jobs with benefits and of higher quality. That is more desirable from the point of view of the social security system, given that if workers engage in formal jobs from an early age, they will contribute more to the pension system. These contributions are important, because by the end of the work life cycle people are more likely to be hired for jobs that are informal or to be self-employed. These workers do not usually contribute to the pension system, which represents a critical condition as they age, because they will not have access to retirement funds.

Overall, job quality in Colombia has differences with the ones in OECD countries. Recently the OECD made a study of job quality for a group of emerging economies, including Colombia (OECD, 2015). They study three dimensions of the quality of jobs: Earnings Quality, Labor Market (In)security and Quality of Working Environment. The study highlights that all the three dimensions exhibit lower standards in emerging economies than in the OECD countries. Specifically, lower Earning Quality and Quality of Working Environment, accompanied by higher Labor Market Insecurity. OECD (2015) also finds that emerging economies face high incidence of informality. Particularly, in urban Colombia "some workers may become trapped in a vicious circle between informal jobs and non-standard formal jobs", because informal workers who transit to formality tend to move to temporary jobs, with high probability of falling back into informality. If Colombia aims to be accepted in this developed-countries club, some improvements may be necessary, in particular a reduction in job informality.

\section{References}

Arango, L. E., \& Hamann, F. (Eds.). (2012). El mercado de trabajo en Colombia: hechos, tendencias e instituciones. Bogotá: Banco de la República.

Agovino, M. \& Parodi, G. (2014). Identifying the Quality of Work by Fuzzy Sets Theory: A Comparison Between Disable and Non-disabled Workers. Social Indicators Research, 119(3), 1627-1648.

Bérenger, V. \& Verdier-Chouchane, A. (2007). Multidimensional Measures of Well-Being: Standard of Living and Quality of Life across Countries. World Development, 35(7), 1259-1276.

Blank, R.M. (1990). Are part-time jobs bad jobs? In Burtless, G. (Ed.) A Future of Lousy Jobs? The Changing Structure of U.S Wages (pp. 123-64). Washington, DC: Brookings Inst.

Bustamante, C.D. \& Arroyo, S. (2008). La raza como determinante del acceso a un empleo de calidad: un estudio para Cali. Revista Ensayos sobre Política Económica, 26(57), 130-175. 
Cheli, B. \& Lemmi, A. (1995). A "Totally" Fuzzy and Relative Approach to the Multidimensional Analysis of Poverty. Economic Notes by Monte dei Paschi di Siena, 24(1), 115-134.

Clark, A.E. (1996). Job Satisfaction in Britain. British Journal of Industrial Relations, 34(2), 189217.

Clark, A.E. (2005). Your Money or Your Life: Changing Job Quality in OECD Countries. British Journal of Industrial Relations, 43(3), 377-400.

Dahl, S.; Nesheim, T. \& Olsen, K. (2009). Quality of work-concept and measurement. Working Papers on the Reconciliation of Work and Welfare in Europe, REC-WP 05/2009.

Davoine, L. (2006). Are quantity and quality of Jobs correlated? Using, interpreting and discussing the Laeken indicators. Document de travail, No. 59. Centre D'Etudes de L'Emploi.

Desai, M. \& Shah, A. (1988). An econometric approach to the measurement of poverty. Oxford Economic Papers (40), 505-522.

Dueñas, D.; Iglesias, C. \& Llorente, R. (2009). La Calidad del empleo en un contexto regional con especial referencia a la Comunidad de Madrid. Universidad de Alcalá, Serie Documentos de Trabajo, (05), 1-36.

Dupuis, G.; Taillefer, M.-C.; Etienne, A.-M.; Fontaine, O.; Boivin, O. S. \& Von Turk, A. (2000). Measurement of quality of life in cardiac rehabilitation. In J. Jobin, F. Maltais, \& P. Leblanc (Eds.). Advances in cardiopulmonary rehabilitation (pp. 247-273). Champaign: Human Kinetics Publishers.

Farné, S. (2003). Estudio sobre la calidad del empleo en Colombia. Resource document. OIT. http://white.oit.org.pe/osra/documentos/farne_dic9.pdf

Farné, S.; Vergara, C.A \& Baquero, N. (2011). La calidad del empleo en medio de la flexibilización laboral. Colombia 2002-2010. Observatorio del mercado de trabajo y la seguridad social. Universidad Externado de Colombia.

Freeman, R.B. (1978). Job Satisfaction as an Economic Variable. The American Economic Review, 68(2), 135-141.

Galvis, L.A (2012). Informalidad laboral en las áreas urbanas de Colombia. Coyuntura económica: Investigación económica y social, XLII(1), 15-51.

Gittleman, M.B. \& Howell, D.R. (1995). Changes in the Structure and Quality of Jobs in the United States: Effects by Race and Gender, 1973-1990. Industrial and Labor Relations Review, 48(3), 420-440.

Gómez, M.; Galvis, L.A \& Aroca, P. (2013). Conmutación de larga distancia en Chile: el efecto de la calidad del empleo sobre la distancia y la probabilidad de conmutar [Mimeo]. Universidad Católica del Norte, Antofagasta-Chile.

Gruenberg, B. (1980). The Happy Worker: an Analysis of Educational and Occupational Differences in Determinants of Jobs Satisfaction. American Journal of Sociology, 86(2), 247-71.

Huneeus, F.; Landerretche, O \& Puentes, E. (2012) Multidimensional Measure of Job Quality Persistence and Heterogeneity in a Developing Country. Series Documentos de Trabajo, (357). Departamento de Economía, Universidad de Chile.

Iglesias Fernández, C.; Llorente Heras, R. \& Dueñas Fernández, D. (2011). Calidad del empleo y satisfacción laboral en las regiones españolas. Un estudio con especial referencia a la Comunidad de Madrid, Investigaciones Regionales, 19, 25-49.

Jencks, C.; Pearlman, L. \& Rainwater, L. (1988). What is a Good Job? A New Measure of Labor Market Success. American Journal of Sociology, 93(6), 1322-57. 
Jiménez, D.M. \& Páez, J.N. (2014). Una metodología alternativa para medir la calidad del empleo en Colombia (2008 -2012). Revista Sociedad y Economía, (27), 129-154.

Kalleberg, A.L. \& Marsden, P.V. (2012). Changing work values in the United States, 1973-2006. Social Science Research, http://dx.doi.org/10.1016/j.ssresearch.2012.09.012.

Kohl, M. L. \& Schooler, C. (1982). Job conditions and personality: A longitudinal assessment of reciprocal effects. American Journal of Sociology, 87(6), 1257-1286.

Lelli, S. (2001). Factor Analysis vs. Fuzzy Sets Theory: Assessing the influence of Different Techniques on Sen's Functioning Approach. Discussions Paper Series (DPS), Department of Economics, Katholieke Universiteit Leuven.

Lemmi, A. \& Betti, G. (2006). Fuzzy Set Approach to Multidimensional Poverty Measurement. Springer. New York. ISBN 978-0387-34249-8.

Martel, J. \& Dupuis, G. (2006). Quality of Work Life: Theoretical and Methodological Problems, and Presentation of a New Model and Measuring Instrument. Social Indicators Research, 77(2), 333368.

Mora, J.J. \& Ulloa, M.P. (2011). Calidad del Empleo en las principales ciudades Colombianas y endógeneidad de la educación. Revista de Economía Institucional, 13(25), 163-177.

Muñoz de Bustillo Llorente, R., \& Fernández Macías, E. (2005). Job satisfaction as an indicator of the quality of work. The Journal of Socio-Economics, 34(5), 656-673.

Observatorio del Mercado Laboral de Cartagena y Bolívar (2013). La calidad del empleo en la ciudad de Cartagena 2007-2011. ISBN 978-958-8736-46-4.

OECD (2008) Handbook on Constructing Composite Indicators, OECD Publishing, Paris.

OECD (2013a). Estudios económicos de la OCDE COLOMBIA Evaluación económica. OECD Publishing.

OECD (2013b). Unemployment rate. Employment and Labour Markets: Key Tables from OECD, No. 1, doi: http://dx.doi.org/10.1787/unemp-table-2013-1-en

OECD (2014a). OECD Employment Outlook 2014. OECD Publishing, Paris. http://dx.doi.org/10.1787/emple_outlook-2014-en

OECD (2014b). Executive Summary. OECD Territorial Reviews: Colombia 2014. Resource document. OECD Publishing. http://dx.doi.org/10.1787/9789264224551-3-en

OECD (2015). OECD Employment Outlook 2015. OECD Publishing, Paris. http://dx.doi.org/10.1787/emple_outlook-2015-en

Ortiz, C. H. \& Uribe, J. I. (2006). Informalidad laboral en el área metropolitana de Cali 1992-1998. In J. I. Uribe (Ed.), Ensayos de economía aplicada al mercado laboral. Programa Editorial Universidad del Valle.

Ortiz C.; Uribe, J.; Posso, C.M. \& García, G.A. (2007). Exclusión social en el mercado laboral del Valle del Cauca: desempleo y calidad del empleo 2001-2006. Informe final para el PNUD (Desarrollo Humano para el Valle del Cauca).

Pineda, J. \& Acosta, C. (2011). Calidad del trabajo: Aproximaciones teóricas y estimación de un índice compuesto. Revista Ensayos sobre Política Económica, 29(65), 60-105.

Posso, C.M. (2010). Calidad del empleo y segmentación laboral: un análisis para el mercado laboral Colombiano 2001-2006. Desarrollo y Sociedad, (65), 191-234.

Quiñones, M. (2011). El índice de calidad del empleo, una propuesta alternativa aplicada a Colombia. Documento de trabajo, No. 136. 
Ritter, J.A. (2005). Patterns of Job Quality Attributes in the European Union. Working Paper, 51. ILO.

Rogerson, R.J. (1997). Quality of life in Britain. Glasgow: Quality of Life Research Group, Department of Geography, University of Strahclyde.

Rosenthal, N.H. (1989). More than wages at issue in job quality debate. Monthly Labor Review, (112), 4-8.

Royuela, V., Lopez-Tamayo, J., \& Suriñach, J. (2008). The Institutional vs. the Academic Definition of the Quality of Work Life. What is the Focus of the European Commission? Social Indicators Research, 86(3), 401-415.

Royuela, V., Lopez-Tamayo, J., \& Suriñach, J. (2009). Results of a quality of work life index in Spain. A comparison of survey results and aggregate social indicators. Social Indicators Research, 90(2), 225-241.

Royuela, V., \& Suriñach, J. (2012). Quality of work and aggregate productivity. Social Indicators Research, 113(1), 37-66.

Sen, A.K. (1999). Desarrollo y Libertad. Editorial Planeta. Barcelona.

Spector, P. E. (1997). Job satisfaction: Application, assessment, causes, and consequences (Vol. 3). Sage.

Turcotte, P. R. (1988). QVT: La Qualite de Vie au Travail: Une Voie vers l'Excellence. Montreal: Agence d'ARC.

Zimmermann H.J. \& Zysno P. (1983). Decisions and evaluations by hierarchical aggregation of information. Fuzzy Sets and Systems, 10(1), 243-260. 
Appendix 1. Unemployment Rate in OECD and South American Countries, 2005 and 2013.

\begin{tabular}{|c|c|c|c|c|c|}
\hline Country & 2005 & 2013 & Country & 2005 & 2013 \\
\hline Australia & 5.0 & 5.7 & Argentina & 10.6 & 7.5 \\
\hline Austria & 5.2 & 4.9 & Bolivia & 5.4 & 2.6 \\
\hline Belgium & 8.4 & 8.4 & Brazil & 9.3 & 5.9 \\
\hline Canada & 6.7 & 7.1 & Chile & 8.0 & 6.0 \\
\hline Chile & 8.0 & 6.0 & Colombia & 12.0 & 10.5 \\
\hline Czech Republic & 7.9 & 6.9 & Ecuador & 6.6 & 4.2 \\
\hline Denmark & 4.8 & 7.0 & Paraguay & 5.8 & 5.2 \\
\hline Estonia & 7.9 & 8.8 & Peru & 5.2 & 3.9 \\
\hline Finland & 8.4 & 8.2 & Uruguay & 9.0 & 6.6 \\
\hline France & 8.9 & 10.4 & Venezuela & 11.4 & 7.5 \\
\hline Germany & 11.1 & 5.3 & $\begin{array}{l}\text { Latin America and the } \\
\text { Caribbean (all income levels) }\end{array}$ & 8.0 & 6.2 \\
\hline Greece & 9.8 & 27.3 & $\begin{array}{l}\text { Latin America and the } \\
\text { Caribbean (only developing) }\end{array}$ & 7.6 & 6.0 \\
\hline Hungary & 7.2 & 10.2 & & & \\
\hline Iceland & 2.6 & 5.6 & & & \\
\hline Ireland & 4.3 & 13.1 & & & \\
\hline Israel & 9.0 & 6.3 & & & \\
\hline Italy & 7.7 & 12.2 & & & \\
\hline Japan & 4.4 & 4.0 & & & \\
\hline Korea & 3.7 & 3.1 & & & \\
\hline Luxembourg & 4.5 & 5.9 & & & \\
\hline Mexico & 3.5 & 4.9 & & & \\
\hline Netherlands & 4.7 & 6.7 & & & \\
\hline New Zealand & 3.8 & 6.2 & & & \\
\hline Norway & 4.6 & 3.5 & & & \\
\hline Poland & 17.7 & 10.4 & & & \\
\hline Portugal & 7.6 & 16.5 & & & \\
\hline Slovak Republic & 16.2 & 14.2 & & & \\
\hline Slovenia & 6.5 & 10.2 & & & \\
\hline Spain & 9.3 & 26.6 & & & \\
\hline Sweden & 7.8 & 8.1 & & & \\
\hline Switzerland & 4.4 & 4.4 & & & \\
\hline Turkey & 10.6 & 10.0 & & & \\
\hline United Kingdom & 4.8 & 7.5 & & & \\
\hline United States & 5.2 & 7.4 & & & \\
\hline OECD-Total & 6.6 & 8.0 & & & \\
\hline
\end{tabular}

Source: World Development Indicators, http://data.worldbank.org/. 
Appendix 2. Job Quality Index in Colombia: Literature Review.

\begin{tabular}{|c|c|c|c|}
\hline Author & Dimensions & Variables & Methodology to calculate the index \\
\hline \multirow{4}{*}{ Farné (2003) } & Income & Total monthly labor income (including monetary compensation and in-kind) & \multirow{4}{*}{$\begin{array}{l}\text { The author gives ad hoc horizontal weights (for the } \\
\text { categories of the variable) and vertical (as employed or } \\
\text { self-employed). Outcome variable: an index with } \\
\text { values ranging from } 0 \text { to } 100 \text {, the closer } 100 \text { the better } \\
\text { the quality. }\end{array}$} \\
\hline & Type of contract & Employment contract (written or verbal), term (indefinite or definite) & \\
\hline & Affiliation to social security & Affiliation to social security (health and pension) & \\
\hline & Working hours & Hours worked per week & \\
\hline $\begin{array}{l}\text { Ortiz et al. } \\
\text { (2007) }\end{array}$ & \multicolumn{3}{|c|}{ The same proposed by Farné (2003) } \\
\hline $\begin{array}{l}\text { Bustamante \& } \\
\text { Arroyo (2008) }\end{array}$ & \multicolumn{3}{|c|}{ The same proposed by Farné (2003) } \\
\hline Posso (2010) & \multicolumn{3}{|c|}{ The same proposed by Farné (2003) } \\
\hline $\begin{array}{l}\text { Mora \& Ulloa } \\
\quad(2011)\end{array}$ & \multicolumn{3}{|c|}{ The same proposed by Farné (2003), with minor modifications to the categorization of variables. } \\
\hline \multirow{17}{*}{$\begin{array}{c}\text { Pineda \& } \\
\text { Acosta }(2011)\end{array}$} & \multirow{3}{*}{$\begin{array}{l}\text { Intensity and working } \\
\text { conditions }\end{array}$} & Working hours or workday & \multirow{17}{*}{$\begin{array}{l}\text { The weights of each variable are obtained through the } \\
\text { Analysis of Principal Components-APC. Outcome } \\
\text { variable: an index with values ranging from } 0 \text { to } 100 \\
\text { percentage points, the closer } 100 \text { best quality. }\end{array}$} \\
\hline & & Workplace & \\
\hline & & Overtime pay & \\
\hline & \multirow{3}{*}{ Income } & Income relative to the minimum legal wage & \\
\hline & & $\begin{array}{l}\text { Difference between the observed hourly labor income and labor income per hour, estimated } \\
\text { with Mincerian functions }\end{array}$ & \\
\hline & & Subsidies received from work & \\
\hline & \multirow{3}{*}{ Social security } & Affiliation to social security (pension) & \\
\hline & & Affiliation to social security (health) & \\
\hline & & Professional Risk Coverage & \\
\hline & \multirow{3}{*}{ Job stability } & Membership union or professional association & \\
\hline & & Tenure & \\
\hline & & Term and type of contract & \\
\hline & \multirow{3}{*}{ Perception about the job } & Job satisfaction & \\
\hline & & Work-family compatibility & \\
\hline & & Stability in current job & \\
\hline & \multirow{2}{*}{ Underemployment } & Second job & \\
\hline & & Underemployment & \\
\hline
\end{tabular}

Source: Authors' elaboration. 
Appendix 2. Job Quality Index in Colombia: Literature Review (continue).

\begin{tabular}{|c|c|c|c|}
\hline Author & Dimensions & Variables & Methodology to calculate the index \\
\hline \multirow{32}{*}{ 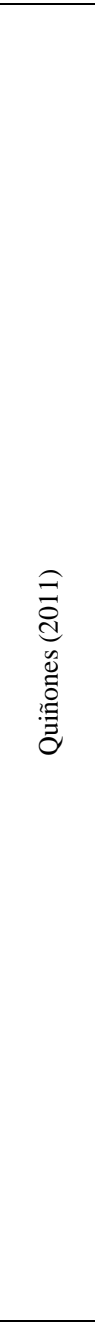 } & \multirow{9}{*}{ Job satisfaction } & Very satisfied with their current job (\%) & \multirow{32}{*}{$\begin{array}{l}\text { Based on Dueñas et al. (2009): "First the data } \\
\text { for each indicator are obtained. Then the mean } \\
\text { and standard deviation of all the regions studied } \\
\text { are calculated. Then those variables are } \\
\text { standardized and converted into } z \text { variables, } \\
\text { such that if a region has positive value in any } \\
\text { variable means such variables are greater than } \\
\text { the middle and lower if it is negative. Finally } \\
\text { the quality index is an average of the } \\
\text { dimensions, in principle giving equal weighting } \\
\text { to each dimension" (p. 13). Outcome variable: } \\
\text { an index with positive values (that is above the } \\
\text { national average) and negative (representing a } \\
\text { decline compared to the national average). }\end{array}$} \\
\hline & & Satisfied with their current job $(\%)$ & \\
\hline & & Dissatisfied with their current job (\%) & \\
\hline & & Very dissatisfied with their current job (\%) & \\
\hline & & Very satisfied with payment for their current job (\%) & \\
\hline & & Satisfied with payment from their current job $(\%)$ & \\
\hline & & Dissatisfied with paying from their current job (\%) & \\
\hline & & Very dissatisfied with paying from their current job $(\%)$ & \\
\hline & & People who want to change jobs because of the working environment $(\%)$ & \\
\hline & \multirow{7}{*}{ Gender equality } & Ratio between men and women of Very satisfied with their current work (\%) & \\
\hline & & Ratio between men and women of Satisfied with their current work (\%) & \\
\hline & & Dissatisfied with their current work between men and women $(\%)$ & \\
\hline & & Ratio between men and women of Very dissatisfied with their current work (\%) & \\
\hline & & Ratio between men and women of Fixed contract $(\%)$ & \\
\hline & & Ratio between men and women of Permanent contract (\%) & \\
\hline & & Ratio of Average income of men and Average income of women & \\
\hline & \multirow{2}{*}{$\begin{array}{c}\text { Health and safety at } \\
\text { work }\end{array}$} & People who say that their work requires much physical or mental effort (\%) & \\
\hline & & People affiliated to a Risk Labor Insurance by the company (\%) & \\
\hline & Flexibility & Actual hours / Usual hours $(\%)$ & \\
\hline & \multirow{3}{*}{$\begin{array}{l}\text { Inclusion and access to } \\
\text { the labor market }\end{array}$} & Employment rate & \\
\hline & & Unemployment rate & \\
\hline & & Both for young people (15-24 years) & \\
\hline & \multirow{6}{*}{$\begin{array}{l}\text { Organization of the } \\
\text { workday and personal } \\
\text { life }\end{array}$} & People who work less than 40 hours per week because it is all they have achieved (\%) & \\
\hline & & People who work less than 40 hours per week because it is that fits their needs $(\%)$ & \\
\hline & & People whose work schedule and family responsibilities are very incompatible (\%) & \\
\hline & & People whose work schedule and family responsibilities are incompatible (\%) & \\
\hline & & People whose work schedule and family responsibilities are compatible (\%) & \\
\hline & & People whose work schedule and family responsibilities are very compatible (\%) & \\
\hline & \multirow{2}{*}{ Social dialogue } & Union members $(\%)$ & \\
\hline & & Non-unionized $(\%)$ & \\
\hline & \multirow{2}{*}{$\begin{array}{l}\text { Overall work } \\
\text { performance }\end{array}$} & Average labor income & \\
\hline & & Share of Temporal Workers (Number of salaried workers with temporary contract to total workers) & \\
\hline
\end{tabular}

Source: Authors' elaboration. 
Appendix 2. Job Quality Index in Colombia: Literature Review (continue).

\begin{tabular}{|c|c|c|c|}
\hline Author & Dimensions & Variables & Methodology to calculate the index \\
\hline \multirow{13}{*}{$\begin{array}{l}\text { Farné et al. } \\
\text { (2011) }\end{array}$} & \multirow{3}{*}{ Job opportunities } & Minor workers & \multirow{13}{*}{$\begin{array}{l}\text { The weights of the variables are obtained through Principal } \\
\text { Component Analysis in its categorical version - CATPCA. } \\
\text { Outcome variable: an index with values between } 0 \\
\text { (minimum quality of employment) and } 100 \text { (maximum } \\
\text { quality of employment). }\end{array}$} \\
\hline & & Female participation in leadership positions & \\
\hline & & (In)formality & \\
\hline & \multirow{3}{*}{$\begin{array}{c}\text { Flexibility and stability } \\
\text { of work }\end{array}$} & Involuntary part-time employment & \\
\hline & & Occupational category & \\
\hline & & Tenure & \\
\hline & Conditions of work & Workplace & \\
\hline & Social security & Social security affiliation & \\
\hline & \multirow{2}{*}{ Income } & Labor income ranges as minimum wage & \\
\hline & & Observed vs potential labor income & \\
\hline & \multirow{2}{*}{ Job satisfaction } & Underemployment & \\
\hline & & Desire to change jobs & \\
\hline & $\begin{array}{l}\text { Compatibility of work } \\
\text { and family life (not } \\
\text { working) }\end{array}$ & Hours worked & \\
\hline $\begin{array}{l}\text { Observatorio } \\
\text { del Mercado } \\
\text { Laboral de } \\
\text { Cartagena y } \\
\text { Bolívar (2013) }\end{array}$ & \multicolumn{2}{|c|}{ The same proposed by Pineda \& Acosta (2011) with changes in the Income and Social Security dimensions } & $\begin{array}{c}\text { The proposed method by Farné et al. (2011), Principal } \\
\text { Component Analysis in its categorical version - CATPCA. } \\
\text { Outcome variable: an index with values between } 0 \\
\text { (minimum quality of employment) and } 100 \text { (maximum } \\
\text { quality of employment). }\end{array}$ \\
\hline \multirow{4}{*}{$\begin{array}{l}\text { Jiménez \& } \\
\text { Páez (2014) }\end{array}$} & \multirow{4}{*}{$\begin{array}{l}\text { Only identify variables, } \\
\text { no dimensions }\end{array}$} & Monthly labor income (MLW) & \multirow{4}{*}{$\begin{array}{l}\text { The weights are obtained through a multivariate technique, } \\
\text { Multiple Correspondence Analysis (MCA). Outcome } \\
\text { variable: an index that takes values between } 0 \text { and 1, the } \\
\text { closer one better quality. }\end{array}$} \\
\hline & & Employment contract & \\
\hline & & Social Security & \\
\hline & & Working hours (hours / week) & \\
\hline
\end{tabular}

Source: Authors' elaboration. 
Appendix 3. Dimensions and variables to the quality of work index, descriptive statistics.

\begin{tabular}{|c|c|c|c|c|c|c|c|c|c|c|c|c|}
\hline \multirow{2}{*}{ Dimension } & \multirow{2}{*}{ Variable } & \multirow{2}{*}{ Categories } & \multicolumn{5}{|c|}{2009} & \multicolumn{5}{|c|}{2015} \\
\hline & & & Obs. & Mean & \begin{tabular}{|l} 
Std. Dev. \\
\end{tabular} & Min & Max & Obs. & Mean & Std. Dev. & Min & Max \\
\hline \multirow{9}{*}{$\begin{array}{l}\text { Working } \\
\text { Conditions }\end{array}$} & \multirow{3}{*}{ Hours worked } & 1. More than $48 \mathrm{~h}$ & 63870 & 0.37 & \begin{tabular}{|l|}
0.48 \\
\end{tabular} & 0 & 1 & 72682 & 0.32 & $\begin{array}{r}0.47 \\
\end{array}$ & 0 & 1 \\
\hline & & 2. 48 hours & 63870 & 0.28 & 0.45 & 0 & 1 & 72682 & 0.31 & 0.46 & 0 & 1 \\
\hline & & 3. Less than $48 \mathrm{~h}$ & 63870 & 0.35 & 0.48 & 0 & 1 & 72682 & 0.37 & 0.48 & 0 & 1 \\
\hline & \multirow{4}{*}{ Workplace } & 1. Open space & 63870 & 0.12 & 0.33 & 0 & 1 & 72682 & 0.10 & 0.30 & 0 & 1 \\
\hline & & 2. Vehicle & 63870 & 0.14 & 0.35 & 0 & 1 & 72682 & 0.14 & 0.34 & 0 & 1 \\
\hline & & 3. Kiosk & 63870 & 0.11 & 0.31 & 0 & 1 & 72682 & 0.12 & 0.32 & 0 & 1 \\
\hline & & 4. Office & 63870 & 0.63 & 0.48 & 0 & 1 & 72682 & 0.64 & 0.48 & 0 & 1 \\
\hline & \multirow{2}{*}{ Overtime paid } & 1. No overtime paid & 63870 & 0.97 & 0.17 & 0 & 1 & 72682 & 0.94 & 0.24 & 0 & 1 \\
\hline & & 2. Paid overtime & 63870 & 0.03 & 0.17 & 0 & 1 & 72682 & 0.06 & 0.24 & 0 & 1 \\
\hline \multirow{9}{*}{ Income } & \multirow{4}{*}{$\begin{array}{l}\text { Income (in relation to the minimum } \\
\text { hourly wage) }\end{array}$} & 1. Up to one minimum wage & 63870 & 0.47 & 0.50 & 0 & 1 & 72682 & 0.43 & 0.49 & 0 & 1 \\
\hline & & 2. Between 1 and 3 minimum wage & 63870 & 0.41 & 0.49 & 0 & 1 & 72682 & 0.46 & 0.50 & 0 & 1 \\
\hline & & 3. Between 3 and 5 minimum wage & 63870 & 0.07 & 0.25 & 0 & 1 & 72682 & 0.06 & 0.24 & 0 & 1 \\
\hline & & 4. More than 5 minimum wage & 63870 & 0.05 & 0.22 & 0 & 1 & 72682 & 0.04 & 0.21 & 0 & 1 \\
\hline & \multirow{5}{*}{ Subsidies } & 1. No subsidies & 63870 & 0.70 & 0.46 & 0 & 1 & 72682 & 0.67 & 0.47 & 0 & 1 \\
\hline & & 2. One subsidy & 63870 & 0.18 & 0.38 & 0 & 1 & 72682 & 0.21 & 0.41 & 0 & 1 \\
\hline & & 3. Two subsidies & 63870 & 0.11 & 0.32 & 0 & 1 & 72682 & 0.12 & 0.32 & 0 & 1 \\
\hline & & 4. Three subsidies & 63870 & 0.01 & 0.08 & 0 & 1 & 72682 & 0.01 & 0.08 & 0 & 1 \\
\hline & & 5. Four subsidies & 63870 & 0.00 & 0.01 & 0 & 1 & 72682 & 0.00 & 0.01 & 0 & 1 \\
\hline \multirow{10}{*}{ Social Security } & \multirow{3}{*}{ Affiliation to pension* } & 1. No affiliation & 63870 & 0.57 & 0.49 & 0 & 1 & 72682 & 0.52 & 0.50 & 0 & 1 \\
\hline & & 2. Affiliated 1 & 63870 & 0.05 & 0.21 & 0 & 1 & 72682 & 0.06 & 0.25 & 0 & 1 \\
\hline & & 3. Affiliated 2 & 63870 & 0.38 & 0.49 & 0 & 1 & 72682 & 0.41 & 0.49 & 0 & 1 \\
\hline & \multirow{3}{*}{ Affiliation to health services* } & 1. No affiliation & 63870 & 0.51 & 0.50 & 0 & 1 & 72682 & 0.48 & 0.50 & 0 & 1 \\
\hline & & 2. Affiliated 1 & 63870 & 0.10 & 0.30 & 0 & 1 & 72682 & 0.10 & 0.29 & 0 & 1 \\
\hline & & 3. Affiliated 2 & 63870 & 0.39 & 0.49 & 0 & 1 & 72682 & 0.43 & 0.49 & 0 & 1 \\
\hline & \multirow{2}{*}{ Professional Risk Coverage (ARL) } & 1. No affiliation & 63870 & 0.60 & 0.49 & 0 & 1 & 72682 & 0.54 & 0.50 & 0 & 1 \\
\hline & & 2. Affiliated & 63870 & 0.40 & 0.49 & 0 & 1 & 72682 & 0.46 & 0.50 & 0 & 1 \\
\hline & \multirow{2}{*}{ Severance payments } & 1. No & 63870 & 0.63 & 0.48 & 0 & 1 & 72682 & 0.59 & 0.49 & 0 & 1 \\
\hline & & 2. Yes & 63870 & 0.37 & 0.48 & 0 & 1 & 72682 & 0.41 & 0.49 & 0 & 1 \\
\hline
\end{tabular}


Appendix 3. Dimensions and variables to the quality of work index, descriptive statistics (continue).

\begin{tabular}{|c|c|c|c|c|c|c|c|c|c|c|c|c|}
\hline \multirow{2}{*}{ Dimension } & \multirow{2}{*}{ Variable } & \multirow{2}{*}{ Categories } & \multicolumn{5}{|c|}{2009} & \multicolumn{5}{|c|}{2015} \\
\hline & & & Obs. & Mean & Std. Dev. & Min & Max & Obs. & Mean & Std. Dev. & Min & Max \\
\hline \multirow{10}{*}{ Labor Stability } & \multirow{2}{*}{ Union membership } & 1. No affiliation & 63870 & 0.98 & \begin{tabular}{|l|}
0.14 \\
\end{tabular} & 0 & 1 & 72682 & 0.96 & $\begin{array}{l}0.18 \\
\end{array}$ & 0 & 1 \\
\hline & & 2. Affiliated & 63870 & 0.02 & 0.14 & 0 & 1 & 72682 & 0.04 & 0.18 & 0 & 1 \\
\hline & \multirow{4}{*}{ Tenure } & 1. Up to one year & 63870 & 0.33 & 0.47 & 0 & 1 & 72682 & 0.38 & 0.49 & 0 & 1 \\
\hline & & 2. One to three years & 63870 & 0.22 & 0.41 & 0 & 1 & 72682 & 0.21 & 0.41 & 0 & 1 \\
\hline & & 3. Three to five years & 63870 & 0.12 & 0.33 & 0 & 1 & 72682 & 0.11 & 0.31 & 0 & 1 \\
\hline & & 4. More than five & 63870 & 0.34 & 0.47 & 0 & 1 & 72682 & 0.30 & 0.46 & 0 & 1 \\
\hline & \multirow{4}{*}{ Term and type of contract } & 1. Unpaid & 63870 & 0.47 & 0.50 & 0 & 1 & 72682 & 0.37 & 0.48 & 0 & 1 \\
\hline & & 2. No contract & 63870 & 0.12 & 0.32 & 0 & 1 & 72682 & 0.20 & 0.40 & 0 & 1 \\
\hline & & 3. Written temporary contract & 63870 & 0.13 & 0.34 & 0 & 1 & 72682 & 0.14 & 0.35 & 0 & 1 \\
\hline & & 4. Written permanent contract & 63870 & 0.28 & 0.45 & 0 & 1 & 72682 & 0.29 & 0.46 & 0 & 1 \\
\hline \multirow{6}{*}{ Employment Perception } & \multirow{2}{*}{ Job satisfaction } & 1. Unsatisfied & 63870 & 0.14 & 0.35 & 0 & 1 & 72682 & 0.17 & 0.37 & 0 & $\overline{1} 1$ \\
\hline & & 2. Satisfied & 63870 & 0.86 & 0.35 & 0 & 1 & 72682 & 0.83 & 0.37 & 0 & 1 \\
\hline & \multirow{2}{*}{ Work-family compatibility } & 1. Uncompatible & 63870 & 0.08 & 0.28 & 0 & 1 & 72682 & 0.13 & 0.34 & 0 & 1 \\
\hline & & 2. Compatible & 63870 & 0.92 & 0.28 & 0 & 1 & 72682 & 0.87 & 0.34 & 0 & 1 \\
\hline & \multirow{2}{*}{ Job stability } & 1. Unestable & 63870 & 0.33 & 0.47 & 0 & 1 & 72682 & 0.27 & 0.44 & 0 & 1 \\
\hline & & 2. Stable & 63870 & 0.67 & 0.47 & 0 & 1 & 72682 & 0.73 & 0.44 & 0 & 1 \\
\hline \multirow{6}{*}{ Underemployment } & \multirow{2}{*}{ Second job } & 1. Has two jobs & 63870 & 0.06 & 0.23 & 0 & 1 & 72682 & 0.07 & 0.25 & 0 & 1 \\
\hline & & 2. Does not have a second job & 63870 & 0.94 & 0.23 & 0 & 1 & 72682 & 0.93 & 0.25 & 0 & 1 \\
\hline & \multirow{4}{*}{ Underemployment** } & 1. Three underemployment conditions & 63870 & 0.03 & 0.18 & 0 & 1 & 72682 & 0.04 & 0.19 & 0 & 1 \\
\hline & & 2. Two underemployment conditions & 63870 & 0.14 & 0.35 & 0 & 1 & 72682 & 0.16 & 0.36 & 0 & 1 \\
\hline & & 3. One underemployment condition & 63870 & 0.15 & 0.36 & 0 & 1 & 72682 & 0.12 & 0.33 & 0 & 1 \\
\hline & & 4. No Underemployment & 63870 & 0.67 & 0.47 & 0 & 1 & 72682 & 0.68 & 0.47 & 0 & 1 \\
\hline
\end{tabular}

Notes:

* For health and pension variables "Affiliated 1" corresponds to the worker who are affiliated and pay the entire membership, while "Affiliated 2" corresponds to the worker who are affiliated but their employers pay part or all of the workers membership.

** There are three types of underemployment in the survey: insufficient hours, lack of matching skills and insufficient income.

Source: Authors' elaboration. 